\title{
Practicing Belonging?
}

\section{Non-religiousness in Twenty-First Century Japan}

\author{
Fujiwara Satoko \\ University of Tokyo, Japan \\ fujiwara@l.u-tokyo.ac.jp
}

\begin{abstract}
This article suggests a way for scholars of Japanese religion to contribute to the international discussion on "nones" or the "non-religious," who have been characterized as "believing without belonging," "belonging without believing," "believing in belonging," etc. by integrating three different discursive arenas: one on multiple secularities as a context-conscious reexamination of functional differentiation; one on Japanese modernization centered on the idea of ie (household)-mura (village community); and one on a recent Japanese obsession with tsunagari (relationships, connection) and shōnin (recognition). The article argues that Japanese non-religiousness in the 2010 is an updated, self-conscious version of "religion as human relationships," which can be paraphrased as "practicing belonging." Moreover, while the current "religion as human relationships" practiced among young people tends to be confined to the intimate sphere, its traditional version regulated the public sphere as well. It was this public sphere of "religion as human relationships" that came to appear secular, as opposed to World Religions as matters of personal choice, in the process of modernization, which included the adoption of the Western concepts of "religion" and "secular." The article also suggests that a "relationships turn" has been taking place not only in nonreligious rituals and festivals but also in spiritual culture and institutionalized religion.
\end{abstract}

\section{Keywords}

non-religiousness - nones - tsunagari (relationships, belonging) - ie-mura system modernization 
Monika Wohlrab-Sahr, one of the directors of the Multiple Secularities project, argues that secularity is closely related to non-religiosity as a "habit with reference to religion" is closely related to the "societal framework of secularity." The reason for this, she explains, is that "secularity as a societal configuration within which the boundaries towards religion are drawn attaches a connotation not only to the perception of being religious but also to that of not being religious" (Wohlrab-Sahr 2016: 252). Whereas the other director of the project, Christoph Kleine, has been investigating possible continuities in Japanese secularity from the pre-modern to the modern period, this article explores the issue of secularity in light of Japanese non-religiousness. That is, it offers a possible interpretation of secularity in terms of non-religiousness that complements and complicates understandings of secularity based on references to being religious.

Academic interest and research on non-religiousness, or "nones," in Western countries have grown over the past decade (e.g., Woodhead 2016, 2017; Baker and Smith 2015). Scholars of Japanese religions may feel tempted to compare Western nones with the famous discourses on Japanese 'non-religiousness' (mushūkyō 無宗教), which have been prevalent in post-World War II Japan. We have repeatedly been told by scholars and laypeople alike that the Japanese are unique in the world because the majority of them are non-religious. Now, thanks to comparative studies from elsewhere, we have the opportunity to move beyond the nihonjinron 日本人論 discourses of Japanese uniqueness - a welcome opportunity, indeed.

Nevertheless, there is at least one problem that hinders sound comparison. Woodhead has found that a typical British none is:

younger, white, British-born, liberal about personal life and morals, varied in political commitment but cosmopolitan in outlook, suspicious of organised religion but not necessarily atheist, and unwilling to be labelled as religious or to identify with a religious group. Other than that, my surveys do not reveal any particularly significant correlations - not by class, education, gender, political inclination or region. Nones are distributed throughout the population, and exhibit considerable diversity. They are not a distinct minority, but a confident and rather unselfconscious majority.

WOODHEAD 2016: 242

In contrast, although there are a number of surveys on Japanese people's views of religion, virtually none of them include data regarding the correlation 
between their views on religion and those on morals and politics. ${ }^{1}$ This might be a side-effect of the myth of Japanese homogeneity. It has probably been assumed that Japanese people are not so morally or politically polarized as to warrant exploring any possible correlation to data on religion. Or, conversely, it might have been assumed that there are too many Japanese non-religious people to draw meaningful correlations with their moral and political tendencies, as they would presumably be no different from the data on Japanese people at large. But none of these assumptions has actually been proven or even tested, despite the fact that even the existence of no correlation could also be an important datum. As a result, despite lengthy discussions on mushūkyō, we do not yet have data to share with international scholars like Woodhead who study nones.

This is not to suggest that scholars of mushūkyō should simply mimic the methods or theories employed to understand nones. It would be unprofitable to hastily take a survey in Japan using the same questionnaires that Woodhead and others have employed. Plenty of discussions would first be needed on how to frame such a survey. ${ }^{2}$ As a preliminary step toward a large-scale, metric comparison, this article attempts a qualitative comparison, which, though limited, may help to frame further research into the similarities and differences between Japanese mushūkyō and Western nones.

Among recent studies on Western nones, one example has been particularly striking for me as a potential entry-point for sophisticated comparison with mushükyō. Based on interviews conducted in England, Abby Day argues that for "anthropocentrics," Day's term that overlaps with nones, ${ }^{3}$ belief is a mat-

1 An exception might be a Nippon Hōsō Kyōkai (NHK) survey taken after the Great Tōhoku Earthquake which asks questions on morals, political views and religious views together, but it was intended to find out the impact of the disaster upon these aspects of Japanese people's attitudes (NHK 2012). Therefore, it is not particularly useful to examine the characteristics of Japanese nones.

2 We may also recognize here a difference in approaches between the British research on nones and the Japanese research on mushūkyō. Woodhead, Day and others first identify people who have answered "none" in surveys. They then look into whether they are entirely secular or practicing something that can broadly be called religious in one sense or another. On the other hand, Japanese scholars have been assuming that mushükyō is more like an aspect of culture rather than the personal identity of individuals. When discussing Japanese mushūkyō, Yanagawa Kei'ichi, whom I will refer to heavily in this article, did not ask each and every participant of a particular Obon festival (which he argues to be a mushūkyō practice) whether or not he/she thinks him/herself to be non-religious.

3 Anthropocentrics are "those who do not see a relationship with God at the center of everything they do ... even though some of them identify themselves as Christian in a census" (Day 2011: 157). 
ter of "the social," regardless of whether it be a traditional Christian belief or belief in personal experiences with ghosts or fate (Day 2011: 193). She replaces Grace Davie's "believing without belonging" (Davie 1990) with "believing in belonging" (Day 2011: 181) to describe nones. People who "believe in belonging ... claim social and cultural identities to reinforce a belief in belonging to specific groups of people, particularly those with whom they have affective, adherent relations" (Day 2011: 194). Such groups include not only the living but also the deceased:

By not asking religious questions I was able to draw out beliefs that could only be explained through theories of belongings: atheists who believe in ghosts, for example. Many of my informants often experienced continued belonging with deceased loved ones in what I describe as the sensuous, social supernatural, in contrast to other scholars who would describe such experiences as 'religious.' The everyday, socially situated, non-institutional transcendent experience of continued belonging is brought into being through embodied, physical sensations and emotions and sustained through performative belief rituals where the account is told, re-told, and elaborated.

DAY 2011: 196

Day's arguments and observations resonate with those of Yanagawa Kei'ichi in the 1980s. Yanagawa attempted to articulate the religious nature of Japanese people, who appear to be non-religious in light of the Western notion of religion. He argued that the religion of Japanese people is not based on belief in God. Nor do they have a strong sense of affiliation to a particular religious institution. Instead, their religion is based on human relationships. It is a "religion of human relationships" (ningen kankei no shūkyō 人間関係の宗教) or even "religion as human relationships" (ningen kankei toshite no shūkyō 人間関係として の宗教) (Yanagawa 1984, 1991). Religion as human relationships is composed of various kinds of rituals and festivals centered on different groups of people, such as family, local community, friends and fellow workers. Yanagawa then argues that the human relationships of this non-religious religion also include those with one's ancestors. An example is a traditional Bon festival.

Fundamental to a Bon festival is a service for ancestors or the dead during the Obon period. It is true that a Bon festival has an aspect of entertainment, but its central component is the service. It is a shared assumption that human relationships should be valued, including those between the living and the dead. Therefore, a Bon festival is essential.

YANAGAWA 1984/1991: 67-73 
Yanagawa's idea of "religion as human relationships" without belief in a god resembles Day's "believing in belonging" even more when Day stresses belief's performative aspect: "A process I termed 'performative belief' refers to my neo-Durkheimian construct, where belief is not pre-formed but a lived, embodied performance, brought into being through action and where the object of worship is not an entity such as a god or 'society', but the experience of belonging" (Day 2011: 194). Both Yanagawa and Day thus argue that the "religion" or "belief" of non-religious people is based on "practices of belonging."

Throughout the rest of this article, I write religion in italics as a way to refer to what would be considered "non-religion" or "quasi-religion" under the traditional modern meaning of religion. Therefore, in this article the "religion of non-religious people" is not a categorical mistake but rather a part of my argument. Religion captures the relationality that Yanagawa and Day write about.

Coincidentally, tsunagari つながり, usually translated as "connection" or "relationships" but largely synonymous with Day's "belonging," has been a buzzword in Japanese religious and secular contexts in the 2o10s. Related words such as kizuna 絆 (tie or bond, a word heavily used in relation to the 2011 Great Earthquake), (sōgo 相互) shōnin 承認, ([mutual] recognition), and kyōkan 共 感 (sympathy or feeling together) have also saturated public and scholarly discourse in Japan. Indeed, the concept of tsunagari seems to have become key to exploring contemporary Japanese non-religiousness or religiousness, thus indicating the degree to which mushūkyō and nones might overlap. For example, while scholars used to refer to the popularity of Christian style weddings among Japanese people in their discussion of Japanese non-religiousness, the wedding industry has lately been promoting tsunagari kon つながり婚 (tsunagari wedding) as a post-Christian style wedding. Likewise, Christmas celebration in Japan, among young people in particular, has also been an oft-cited example of their non-religiousness. In the 2010s, however, the media has reported yearly on the streetside Halloween party in Shibuya, Tokyo, which economists call tsunagari shōhiつながり消費 (tsunagari consumption).

This article will investigate whether and how the recent non-religiousness or religiousness centered upon tsunagari is different from Yanagawa's "religion as human relationships," presented as a prototype of Japanese religion. It aims to contribute to the formation of a basis for international comparison of contemporary nones. In so doing, it will also bridge the study of nones with discussions on secularity as an outcome of functional differentiation, which is the common theme of this special issue. While nones are more likely discussed in the context of secularization as the decline of individual faith rather than as differ- 
entiation, this article will show that the idea of relationships bridges the study of nones with the study of multiple secularities.

To make this argument, the article first tracks discussions on secularization and modernization among earlier Japanese scholars. It argues that Yanagawa's idea of "religion as human relationships" was originally presented as a response to the debate on secularization as functional differentiation. The article then introduces recent arguments that try to contextualize the recent obsession with tsunagari among Japanese people, drawing on concrete examples.

Let me start by describing in more detail the aforementioned examples of recent religiousness centered upon tsunagari.

Zexy, Japan's largest wedding magazine, has characterized the wedding of the 2010 as tsunagari kon (tsunagari wedding). Tsunagari kon refers to the trend to "think it essential to appreciate the bond with one's family and close friends who always support him/her, to express one's gratitude to them, and to cherish a vow between a couple." ${ }^{4}$ At a glance, what the quote says may look quite normal, containing nothing remarkable or new. But it is not. A couple creates, often on the suggestion of a wedding company, special rituals to visualize and strengthen their bond. These rituals include, for example, the "ring-relay," "last bite," "cake-cutting by six" and "candle-relay." The "ring-relay" is a relay of a wedding ring along a string from guest-friend to guest-friend. "Last-bite" is a performance in which a bride and bridegroom each ask their mother to let them have a bite of cake, as they did when they were babies. "Cake-cutting by six" is a wedding-cake cutting ceremony in which not only the couple but also parents on both sides cut the cake together. "Candle-relay" is exactly what the name suggests. All these are performed in order to assure the bond between the couple and their parents and guests in an ostentatious way. While the wedding party in Japan used to be an occasion to introduce the bride to the groom's

4 From an interview with Zexy's chief editor conducted by a web magazine, "Tsunagari kon, shea ga ryūkō! つながり婚、シェアが流行！” (Tsunagari wedding and shared wedding are in vogue!), Da Vinci, 2015/7/25. https:/ddnavi.com/tokushu/248854/a/ (accessed March 29, 2019). Also see "Saishin ban kekkonshiki to füfu no katachi: oya yüjin tono kizuna jūshi 最新 版結婚式と夫婦の形一親友人との絆重視 (The latest version of wedding and the style of a marriage: Emphasis on "bonds" with parents and friends)," Asahi Shimbun 朝日新聞, 2013/7/20. 
family and relatives, boss and co-workers, it is turning into a ritual to show appreciation to one's own family (from the bride to her family, from the groom to his family) as well as invitees.

Closely related is another wedding style called sheado kon シェアド婚 (shared wedding), which is a wedding for which a couple and their friends make preparations together. For example, they may collectively create a video or plan a game for all guests. That is, the couple and their guests become united, entertaining each other and sharing happiness from the beginning to the end of the wedding preparation and performance.

Both tsunagari kon and sheado kon can be combined with a Christian or other religious style wedding, but they need not be in order to function as rituals. A sample on Zexy's web magazine, entitled Kokoro no tsunagari o ishiki shita wa modan na kekkonshiki こころのつながりを意識した和モダン な結婚式 (A modern Japanese-style wedding that is conscious of the tsunagari of hearts), shows several pictures of an actual wedding, but none of them include a Shintō priest, let alone a Christian minister. Rather, it is the human relationships that make the wedding an authentic ritual. ${ }^{5}$

These shifts in wedding trends are partially indicative of a broader shift in human relationships in Japan, one that has also been expressed in and affected people's consumption habits. For example, Halloween has become increasingly popular as a commercial event in Japan since around 200o. Tokyo Disneyland and Universal Studios Japan have started offering Halloween parties, and the confectionary industry started producing Halloween cakes and snacks. However, Japanese Halloween soon became something more than a business occasion. Young people in Halloween costumes (somewhat resembling cosplay) began throwing street parties. The best-known party is that held around Shibuya Scramble Crossing. Hundreds of young adults create chaos in collective effervescence all night long. Unlike the street dance fever that took place in Harajuku, Tokyo, in the 1980s, there is no distinction between performers and audience in the Halloween party. Everyone is a part of a moving and shouting mob, experiencing belonging with friends and other young people (NTT Ad 2015). Economists and the media started calling that social phenomenon tsunagari shōhi (tsunagari consumption) around the mid-201os. While people in the 1980s were known for brand shōhi (consumer behavior determined by designer brands) or status shōhi (people tried to get big-name brands as a sign

5 If a Christian minister can so easily be replaced by rituals of human relationships, Jesse LeFebvre's analysis of the Christian wedding in Japan should be reconsidered. He argues that Japanese couples are serious about making a wedding religiously Christian in order to make it authentic (LeFebvre 2015). 
of their social status), young people in the 2010 are no longer interested in buying such commodities. ${ }^{6}$ What they are more committed to is an exciting and special experience of belonging. While holding off on branded clothes and cars, they do not refrain from spending money on Halloween costumes to get that kind of tsunagari experience. It is the tsunagari experience itself that they seek to consume.

Some may wonder whether the tsunagari wedding is really new or a mere revival of traditional religious wedding. At least among scholars of Japanese religions, it is well-known that the Japanese wedding has been "religious" only since the beginning of the twentieth century. Weddings were formerly conducted without priests or other religious functionaries. It was a rite-of-passage event between families and relatives of the couple. Scholars may therefore recognize some religious symbols in the ceremonial part of pre-twentieth century weddings. It was only after the encounter with Western wedding culture that the Japanese wedding started to be modified via the paradigm of world religions, such that there could be a Shintō-style wedding or a Buddhist-style wedding. The premodern wedding was all about families and local communities. Therefore, it is impossible to articulate how the contemporary tsunagari wedding is different from the premodern wedding in Japan within the general expressions of "religion as human relationships" (Yanagawa) and "practicing belonging" (Day). The same holds true with Halloween.

Yanagawa and other scholars have argued that it is normal for participants in a matsuri festival to be unaware of which deities are enshrined or what kind of religious meanings are attached to the festival. The matsuri festivals at which folklorists used to conduct fieldwork and the Shibuya Halloween celebration can both be characterized as events that sacralize human relationships through collective effervescence. Then what are the differences? Undoubtedly, Shibuya Halloween does not involve the dead as do a Bon festival or Halloween as a traditional, folk religious practice. But is that all?

\section{3 "Religion as Human Relationships" in Theoretical Contexts: Between Secularization and Modernization}

Before jumping into the difference between contemporary tsunagari and Yanagawa's idea of "religion as human relationships," allow me to describe the histor-

6 See, for example, Chapter 3 in "White Paper on Consumer Affairs 2017," Consumer Affairs Agency. https://www.caa.go.jp/en/publication/annual_report/2017/ (accessed 29 March 2019). 
ical context of the latter. Note that this context is not separate from the content of my argument. Rather, it is an integral aspect of the difference between contemporary practices of belonging and the relationships involved in Yanagawa's argument.

Yanagawa's argument originally developed as a response to the then dominant Western theory of secularization and can now be seen as an attempt to explore multiple modernities. He argued that, unlike Western secularities, Japanese secularity was not caused by the dis-establishment of the state church in the modern era; Japan took a different path. As such, Yanagawa's argument helps us to bridge discussions on nones with those on multiple secularities. That bridging also serves as a response to an aspect of Ugo Dessi's (2017) critical review of Japanese debate on secularization.

Dessì finds that, among many Japanese scholars of religion, including Yanagawa, "there is the idea that the interplay between religion and other spheres of social life is in Japan somehow unique and cannot be explained through 'western secularization theory' (whatever this may mean)" (Dessì 2017: 64). Although it is true that discussions on secularization have not been as popular in Japan as in Western countries, it does not mean that the works of Japanese scholars during the 1970s had nothing to do with or are not relevant to discussions on multiple secularities. ${ }^{7}$ It is important to note that Yanagawa's critique of the Western theory of secularization was centered on the church-sect typology (derived from Troeltsch and Weber: "church" in the sense of an established, state church, and "sect" in the sense of newly formed protest groups). Dessì passingly criticizes Yanagawa, "according to whom the church played in western societies an integrating function that is not at work in the case of institutional religion in Japan. As such, it reiterates old views of Christianity as a creedal religion centered on dogmas" (Dessì 2017: 63). His critique does not do sufficient justice to Yanagawa because Yanagawa's concept of church derived from the aforementioned typology rather than a view of Christianity as a creedal religion.

It is equally important to realize that what was at stake among Japanese scholars after World War II was modernization-much more so than secular-

7 Readers of Yanagawa's article (Yanagawa and Abe 1978) will notice that the word "secularization" does not appear until the very end of the article. Therefore, they may think that Dessì has overinterpreted the article insofar as he regards it as representing major arguments on secularization among Japanese scholars. This is exactly the point I am making here. What Dessì and his fellow European scholars think to be a secularization debate is, at the same time, a debate on modernization or social change (shakai hendō ron 社会変動論) in the modern era. 
ization. In other words, secularization was not regarded as being tantamount to modernization, and interest in secularization could not match their interest in modernization. Their daily conversation partners were not Western scholars of religion, but rather Japanese scholars in different departments among the humanities and social sciences, who were preoccupied with the question of where Japan went wrong in the process of modernization. Let me explain each of these points.

As for the church-sect typology, Yanagawa (and Abe Yoshiya) argued as follows:

Japanese scholars have made an effort to be true to European sociological theory and, further, to apply it to their analysis of Japanese religious phenomena. They continually ran into difficulties, however, relating to the point that there was, within the European theories, an aspect they found difficult to deal with: the classical subdivisions of (western) religious sociology, church and sect, clearly do not apply to Japanese religion.

YANAGAWA and ABE 1978: 6, emphasis in the original

Neither the Buddhism of the Tokugawa period nor the Shintō of the Meiji era can accurately be called a "church":

there has never developed a "church-type" institution comparable to the Catholic Church of Europe at any time in Japanese history. The established religion during the Tokugawa period was nominally Buddhism, but it was far from monolithic in nature....

State Shinto did not claim even to be a religion; thus, there was no established "church" during this period either. As there was no church as such, there was no development of sects in the Japanese social setting.

YANAGAWA and ABE 1978: 6-7

As seen in Peter Berger's idea of "sacred canopy" and Luckmann's idea of "privatization," Western theories of secularization, at least those which were popular in the 1970s in Japan, identified the disestablishment of the state church, which is not made of sects but a single, dominant church, as the biggest shift toward secularization. Though some sociologists called the process "laicization," as it was also an era of symbolic studies, Bergerian ideas were more prevalent than the French idea of laïcité. Yanagawa and others argued that these Western theories of secularization could not be straightforwardly applied to Japan because it was not the "church" that served to integrate or unify Japanese society. 
Then what institution had functioned to integrate Japanese society? Ie イ⼯ (household) was the answer Yanagawa gave: "the counterpart in Japan of the 'church' in Western societies in terms of the core structure of society has always been and will remain the $i e$ or 'household' in its peculiarly Japanese setting" (Yanagawa and Abe 1978:12). Yanagawa explained the $i e$ in some detail:

One must realize that as a sociological concept, the ie or Japanese household represents a particular social system and not a universally applicable concept like "family." The Japanese household is a particular and peculiar institution based upon Japan's traditional social structure. Its peculiarities are marked, according to Itō Mikiharu, by an emphasis on the legitimacy of genealogy and on its perpetuity.

YANAGAWA and ABE 1978:13

Recent scholars may critique the nihonjinron-like emphasis on Japanese peculiarities in the quote, but it is entirely appropriate to look at lineage and kinship to discover the structure of a society. In addition, the Japanese $i e$ is indeed different from the Chinese zhong zhu 宗族 in the weight given to blood ties and genealogy (Rawski 2015:144-187). What is more important for our argument is that Yanagawa argued that Buddhism formed a sacred canopy for Japanese traditional society, not with norms expressed in creeds and canons, but by being incorporated into the practice of ancestor worship, the central rite of the ie. Moreover, Buddhist orders in Japan themselves adopted the ie structure:

After it [Buddhism] was introduced to Japan, it lost most of its universalist tenets and became closely tied to ancestor worship.... The relationship of all the temples to their shüha resembles a family structure ... Hence in Japanese Buddhism the principle of renouncing this worldly order ... has given way to an alternative cultural form based on the household system. YANAGAWA and ABE 1978: 13

The logical consequence of this argument is that, just as ie is the Japanese equivalent of the Western church, the Japanese equivalent of Western secularization is the dissolution of the $i e$ system, which most visibly appears as decline in ancestor worship. This is why Yanagawa spent half of his article on ancestor worship and how it had been transformed by social changes in the twentieth century. In other words, he attempted to explain secularization in the Japanese context, rather than bluntly denying that there was anything similar to Western secularization in Japan. 
Indeed, what Yanagawa argued in the conclusion of his article can be regarded as a call for the comparative study of multiple secularizations, directed toward international scholars:

In research on a society in which "churches" and "sects" are difficult to identify, problems of a fundamental nature cannot be explored merely by the use of such data as the number of church members, the attendance rate at weekly services, or the amount of donations to the "churches" or "sects." What we have attempted to suggest in this paper is simply that, when it comes to sociological research on a society in which there are no religious institutions comparable to those regarded as central in the west, one needs: (a) to identify target institution(s), and (b) to construct a theoretical framework appropriate to the object(s) of study.

YANAGAWA and ABE 1978: 24

Nevertheless, he did not directly apply the word "secularization" when discussing changes in ancestor worship, possibly because the $i e$ had been a term utilized in the modernization theory of/in Japan.

As I have argued elsewhere (Fujiwara 2008, 2016), discussions on modernization mattered more than those on secularization to Japanese scholars of religion because modernization was the problem considered by postwar Japanese intellectuals (sengo chisikijin 戦後知識人), led by Maruyama Masao, Otsuka Hisao and others. They critically discussed why their society had so easily slid into totalitarianism, and many identified the premodern (or quasi-feudalistic) nature of Japan as the cause. In short, they blamed premodern societal structures for the failure of modernization in Japan. They argued that Japanese people were vulnerable to totalitarianism as they had never become independent citizens with critical awareness, which was a necessary condition to create a mature, modern society. The persistence of the premodern ie system was accused of being a major cause of that "failure" (Ōsawa 2012: 300).

Although there is abundant literature on the $i e$ and modernization, for the present argument, suffice it to say that discussions of $i e$, along with the related idea of mura $ム ラ$ (literally, "village," but as a technical term it is usually written in katakana in order to distinguish it from the normal meaning of village), principally arose from the Japanese adoption of Tönnies's dichotomy of Gemeinschaft (typified by a traditional rural community) and Gesellschaft (typified by a modern, urbanized society). Ie and mura were the terms coined to characterize the Japanese form of Gemeinschaft. Mura is an aggregate of multiple ie, which worship the same ujigami 氏神, a tutelary deity, and hold matsuri festivals together. Briefly put, mura is a community firmly based on blood and locality (chien ketsuen shūdan 地縁血縁集団). 
Critics argued that modern Japanese institutions were masked ie-muras governed by irrational, emotional bonds instead of being formed by independent individuals making rational decisions. Japanese companies were pseudo-ie, and Japanese politics were called mura-seiji ムラ政治 (mura politics). Not to mention the prewar Japanese Empire, which was imagined as a genealogical hierarchy of ie with the emperor on top. And the Meiji constitution, imperial Japan's civil law, explicitly employed the idea of $i e$ and ancestor worship in order to integrate the nation.

After decades of critical assessment, in the late 1970s some scholars started revalorizing the ie-mura system, saying that the system was not an obstacle but rather an impetus for the modernization of Japan. Such pro-ie arguments were represented by economists Murakami Yasusuke and Kumon Shunpei as well as the political scientist Sato Seizaburō, who together published Bunmei to shite no ie shakai 文明としてのイエ社会 (Ie Society as a Pattern of Civilization) in 1979 (Murakami et al. 1979). They argued that Japan had been quite successful in modernization as industrialization precisely because Japanese companies were organized by the ie system, or aidagarashugi 間柄主義 (the principle of relationships), in which family-like harmonious relationships took precedence over individual aspiration. Their arguments, soon supplemented by "Japan as No. 1" discourses and the popularized theory of nihonteki keiei 日本的経営 (Japanese-style management), faded away after the collapse of Japanese economy in the mid-199os. While acknowledging their naïve, nativistic tendencies, in retrospect, these debates on ie can be regarded as early attempts to theorize multiple modernities or to trace the path dependency of Japanese modernity. A well-reviewed, major encyclopedia of contemporary sociology published in 2012 gives the following summary and evaluation of the debates:

In the latter half of the 1970s, some scholars tried to draw general social scientific theories from Japanese experiences of modernization. They argued that modernization had multiple paths, against the monophyletic theory of modernization, in which Western history was considered to be the only model of modernization. An example is Murakami et al. 1979, who argued that the traditional $i e$ society of Japan provided a basis for modernization. Furthermore, more than a few social scientists have attempted to critically reinterpret the modern history of Japan by carefully reflecting on both the early criticism of Japanese modernity from academic (kōzaha 講座派) and societal (shimin shakai ha 市民社会派) groups [i.e., Maruyama and Otsuka] and its later affirmation [i.e., Murakami et al.].

ŌSAWA 2012: 300 
While self-conceited arguments valorizing nihonteki keiei are quite embarrassing today, more neutral usages of the idea of $i e$ and mura have not yet been dismissed among Japanese social scientists. For example, a college textbook of the sociology of religion written by young Japanese scholars in 2012 spends four pages on the ie-mura theory (Takahashi 2012: 12-15).

Therefore, it would be worthwhile to tentatively accept the theory and see if it contributes to our current discussions on multiple secularities. Christoph Kleine argues that premodern Japanese culture must have "in some way distinguish(ed) between two spheres that we may-from an etic perspectivelabel as 'the religious' and 'the secular'" (Kleine 2013: 5) and that the distinction pre-structured the appropriation of the Western concept(s) of secularity in the nineteenth and twentieth centuries. He claims that, otherwise, Japan would have not become such a highly secular state. Although opinions remain divided over whether or not Japan has been secularized, it can safely be argued that Japan has put up relatively little resistance to the modern Western idea of the separation of religion and the state or of the religious and the secular spheres. Kleine argues that the fundamental Buddhist distinction between things that belong to this world (seken 世間) and those which transcend the world (shusseken 出世間) as well as the medieval Buddhist distinction between the "ruler's law" (ōbo 王法) and the "Buddha's law" (buppō 仏法) were the emic distinctions between "the religious" and "the secular" that became the precondition of secularization in the modern period (Kleine 2013).

To compare Kleine's arguments with the ie-mura theory and Yanagawa's idea of religion as human relationships, it can be said that the former is based on a substantive definition of religion while the latter is based on a functional definition of religion. Kleine focuses on the juxtapositions of seken/shusseken and $\bar{o} b \bar{o} / b u p p \bar{o}$ in the medieval discourses of Buddhism, which is recognized as a religion in the World Religions paradigm. In contrast, the ie-mura system is not a religion under the paradigm but a functional equivalent to Durkheimian religion, the main function of which is to integrate society. Exactly for that reason, in this article I have been italicizing "religion" in Yanagawa's idea of religion as human relationships. Yanagawa would argue that seken/shusseken and $\bar{o} b \bar{o} /$ buppō are ideational constructs deriving from Buddhist "universalist tenets" (see the above quote), and that what actually shaped people's daily lives more substantially was the ie-mura system, with ancestor worship as its religious expression.

How, then, can the ie-mura system, or religion as human relationships, be described using the dichotomy of the religious and the secular? Religion as human relationships is the public religion of a mura community. Personal matters, including voluntary commitments to religious orders (here, religion as 
defined under the World Religions paradigm), belong to the private sphere. ${ }^{8}$ Shukke (shusseken) monastic practices would be one such example. As a practice of cutting ties with one's family and community, it is a denial (even if sometimes only a symbolic one) of religion as human relationships that is a typical practice of religion under the World Religions paradigm. ${ }^{9}$

Conversely, and most important to discussions on multiple secularities, is that in light of the ie-mura system or religion as human relationships, seken turns out to be religious. And that religious seken has been the functional equivalent of "church" as opposed to sect in Europe. While Kleine argues that seken and shusseken are the precedent concepts of modern "secular" and "religious," respectively, from a functionalist viewpoint, it can be argued in a different way. In premodern Japan, social integration was possible without establishing a religion in the sense of the World Religions paradigm. Therefore, as I argue above, religions in the sense of World Religions remained private. If we follow the substantive definition of religion, then that premodern situation was already a secularized society. The public sphere was non-religious, and religions belonged to the private sphere. Indeed, that could be why Japanese people easily adopted the Western idea of secularity in the nineteenth and twentieth centuries, and Japanese society quickly came to look secularized. Religion as human relationships was not regarded as "religion" by Japanese people. The public sphere and the integrating force of the sphere, the ie-mura system, were viewed as secular.

As Yanagawa argues, while Western scholars were debating over secularization, Japanese scholars were concerned with the dissolution of the ie-mura system, as seen in the decline in the practice of ancestor worship. That is, traditional religion as human relationships was declining. The traditional wedding as a ritual of religion as human relationships came to be taken over by an individualistic and selective World Religion-style wedding, first by the "Shintōstyle" and then by the "Christian-style" wedding. Therefore, it is all the more interesting that in the twenty-first century, we see a revival of religion as human relationships typified by the tsunagari wedding, in which human relationships,

8 This might look confusing because religious organizations such as Buddhist orders and new religious groups are also embedded in human relationships. However, they are voluntary associations and not so-called 'naturally' formed communities like mura. Moreover, as Yanagawa (with Abe) argues, Japanese Buddhist orders, shūha 宗派, adopted the ie system as their own organizing principle as part of the process of naturalizing Buddhism.

9 Notably, this structure parallels the (so-called) State Shintō system. State Shintō, in the form of public rituals, claimed to be non-religious, but it was in fact religious, while "religions" such as Christianity and Buddhism were regarded as a matter of private choice. The parallelism is no coincidence: State Shintō was an artificial, nationalist expansion of the $i e$-system. 
much more than priests and symbols of World Religions, matter. Why did this happen, and what is the new religion as human relationships based on, if not on the older ie-mura system?

\section{Over-Connection Syndrome in a Non-relational Society}

In order to tackle these questions, it is necessary to overview recent changes in Japanese society from a broader perspective, as tsunagari is not at all confined to religious or religious contexts. After NHK broadcasted a TV program titled Muen shakai 無縁社会 (Relationless Society) in 2010, the word muen caught not only Japanese but also international scholars' attention. People had already known about the problem of isolation caused by the disintegration of society, but the NH K program shocked the audience by showing actual cases of how terribly the lack of social capital can affect a rapidly aging society. Some scholars of religion started discussing whether or not existing religious organizations could cope with the problem by recreating local networks. These discussions multiplied after the 2011 Great Tōhoku Earthquake.

On the other hand, around the same period, the media and other scholars started arguing about the problem of over-connectedness in Japan, especially among young people. The media reported how Japanese teenagers were pathologically obsessed with social networking services, being unable to turn their smartphones off day and night. "Line," the social networking service introduced to Japan in 2011, quickly became well-known for its addictiveness.

Doi Takayoshi, a sociologist, has named that obsession "tsunagari kajō shōkōgun” つながり過剩症候群, or “over-connection syndrome." He observes that Japanese young people have increasingly come to care too much about how people around them, not strangers but friends or friends-to-be, look at and think about them. He analyzes why young people these days indulge almost pathologically in social networking services (SNS) or, more generally, why they have an obsessive concern for the intimate sphere and a corresponding lack of concern for the public sphere. Doi argues that Japanese society now allows too great a variety of values and makes young people uncertain and uneasy, lacking a socially accepted, distinct model to follow. Consequently, young people depend heavily on recognition or affirmation given by their close pals in order to obtain a sense of self-esteem. They have become overly sensitive of how they are viewed by their friends and are obsessed with keeping smooth relationships with all of them, twenty-four hours a day, through sNs. Mutuallyrecognizing, closed circles typically used to be observed among otaku, who are 
not good at communicating with others in public places but become talkative once logging into a network of like-minded people on the internet. Such a mentality has grown both extreme and prevalent, and young people now care most about the number of "likes" their posts receive on sNs, even more than they care about the content of what their friends and they "like." They push "like" buttons even when they do not like or have not really read their friends' messages, just to avoid isolation. Paradoxically, though desiring to connect with someone in order to feel safe, what they prioritize most in their daily lives is relationships with friends, but conversely, they do not want friendships that are too strong or serious, as they fear that deep relationships can cause conflicts as well. Relationships should be at once lasting and spontaneous. "Over-connection syndrome" refers to such a paradoxical mentality (Doi 2014)..$^{10}$

Doi thus ascribes "over-connectedness" to the desire among young people to be "recognized." It could be said that young people in general have a tendency to suffer from a lack of self-confidence in the struggle to form a personal identity. However, in Japan in the 20oos, Doi and many other social scientists began to argue that Japanese young people have become extremely low in selfesteem and always expect to be "recognized" and "affirmed" by people around them, both in real life and on the net. Accordingly, "recognition" (shōnin 承 認) and the "desire to be recognized" (shōnin yokkyu 承認欲求) have become buzzwords since the mid-20oos. Books titled with the word "recognition" are abundant: Shōnin o meguru yamai 承認をめぐる病 (Disease over recognition) (Saito 2013); “Mitomeraretai" no shōtai: Shōnin fuan no jidai 認められたいの正 体一承認不安の時代 (What is behind “desires to be recognized”: The age of recognition-uncertainty) (Yamatake 2011); Kibōnanmin goikkōsama: Piisu bōto to “Shōnin no kyōdōtai" gensō 希望難民ご一行様—ピースボートと「承認の共 同体」幻想 (Refugees in search of hope: Peace Boat and the illusioned "community of mutual recognition") (Furuichi and Honda 2010); and Shoninyokubō no shakai henkaku 承認欲望の社会変革 (Social upheaval through the desire to be recognized) (Nishio, Yamaguchi and Kusaka 2015), just to name a few. These books range from popular top-sellers to solid academic books published by university presses.

10 This paragraph is a summary of Chapter 1 of Doi (2014). 
Explaining Tsunagari Non-religiousness in the 2010s: How It Differs from the Ie-mura System

Given the popularity of books using terms of relationality and the prevalence of the phenomenon that those terms attempted to describe, it was only natural that some Japanese scholars of religion started employing those buzzwords in their research. ${ }^{11}$ One early attempt to do so can been seen in Koike Yasushi's observation of a change in the spiritual and popularized New Age movements of Japan, which corresponds to the rise in excessive interest in recognition more generally among young people.

Koike's work, published in 2007, describes the change as one "from 'strong self' to 'weak self'” (tsuyoi jiko kara yowai jiko $e$ 強い自己から弱い自己へ) (Koike 2007). "Strong self" is what earlier spiritual movements, or therapeutic culture, attempted to realize by means of American developments in positive thinking and could be found and made in a wide variety of settings, including network marketing by companies such as Amway and awareness training seminars. A "strong self" refers to a person who aims to become a fuller and more perfect self and achieve social success. In contrast, a "weak self" is represented by participants in trauma survivors' movements such as Alcoholics Anonymous, in which participants in pain and suffering care for each other. From the late nineteenth century, in North America, self-help movements oriented toward social success developed roughly simultaneously with those among trauma survivors. In contrast, Koike stresses a shift from the former to the latter that occurred around 2005 in the Japanese context. That is, the rise of the "weak self" Koike describes coincides with the rise of young people with low self-esteem as observed by Doi.

Koike goes on to employ the Giddensian concept of the intimate sphere to analyze the spiritual movements of the late 2ooos. The intimate sphere is normally constituted by loving and close relationships with one's family and friends. However, for people who have traumatic childhood experiences with their families, self-help groups become an alternate intimate sphere by enabling mutual recognition. Referring to his work, Koike argues:

11 A quick look at Japanese Sociological Review, the peer-reviewed journal of the Japan Sociological Society and the most prestigious academic journal in the field, shows that even among purely academic works, the word has become popular in the last decade. There are 362 articles hit with the word tsunagari. When sorted by the "relevancy" of the word, all articles that appear on the first 100 are those published since 2007 (As tsunagari is a relatively common word, it is necessary to see the relevancy score to make sure it is used as a key word). Cf. https://www.jstage.jst.go.jp/browse/jsr/-char/ja (accessed 29 March 2019). 
By analyzing the discourses of self-help groups with themes such as adult children, codependent addicts, and other addictions, I have demonstrated that such groups offer opportunities for weakened selves to talk in a safe zone and be empowered. People's new networks based on "relationships initiated by common problems" (mondai en 問題縁) have the potential to become a therapeutic sphere for mutual recognition and recovery.

KOIKE 2O1O: 113, my emphasis

A more recent attempt to apply the theory of "recognition" to the study of religion is Sakurai Yoshihide's work on "active listening" (keichō 傾聴) as offered by Buddhist priests who tackle the problems of suicide and hikikomoriひきこも り (youth suffering from social withdrawal) in their local communities. Sakurai says that he has examined "the practice of active listening, which aims to respond to modern people's needs for recognition and self-esteem" (Sakurai 2015: 29, my emphasis). He further argues that "The case studies considered here show that self-recognition and recognition by others are important elements of care. Moreover, clinical religion guided by religious scholars and Buddhist monks should not be limited to unidirectional active listening between care-givers and care-receivers, but should be the basis for constructing reciprocal relations in the community" (Sakurai 2015: 29, my emphasis).

Comparing Koike and Sakurai's work with Doi and other scholars' more general arguments on "recognition" and tsunagari, it is remarkable that the former focus upon marginalized individuals with particular problems, while the latter discuss the majority of young people. Moreover, whereas the former argue that spiritual (care) movements can help challenged individuals by providing the basic recognition that they lack elsewhere, the latter problematize overconnection caused by excessive acts of mutual recognition. In other words, both Koike and Sakurai look only at the positive roles of religion and limit the scope of their arguments to spiritual (care) movements. Neither tsunagari kon nor Shibuya Halloween or other similar practices of belonging are included when they discuss recognition and relationships. ${ }^{12}$

12 Nonetheless, Sakurai's general understanding of the social changes of the past few decades is quite similar to Doi's. Such an understanding has been widely shared by Japanese social scientists. As I have only quoted from Doi's work in the main text, here I quote at length from a corresponding part of Sakurai's article to show that Doi's arguments are not unique. Sakurai writes, "In the 198 os, college students aimed to achieve selfrealization ( jikojitsugen 自己実現) through their careers. However, now, after the period of low economic growth called the 'lost 20 years,' they now give priority to the stability of companies in their job searching. In addition, the desire for recognition has intensified among young generations, who have become the precariat. A good example is 
On the other hand, Doi, though not a scholar of religion, may more directly help us articulate the differences between traditional and new religion as human relationships. He makes it clear that the intimate sphere itself has been transforming in recent decades in ways that have affected not just marginalized people, but also much of the general population. Traditional relationships in the intimate sphere were a part of the $i e$, into which people were born. Young people have long tried to escape such relationships in the process of modernization and urbanization. In contrast, Doi argues, in today's society, where both traditional blood-based (ketsuen 血縁) and locality-based (chien 地縁) communities and modern social organizations such as schools and companies have lost their regulating power upon individuals, young people are no longer automatically born into pre-existing human relationships that provide social belonging. Instead, they have to create their own relationships and constantly try to maintain them by themselves. Doi argues:

Needless to say, today's children start making friends with other children in their neighborhood or in the same classroom at school as children in the twentieth century did. However, that institutional basis now plays a very small role in maintaining such initial relationships for the long term. They do not have to be with children with whom they are not on good terms, even if they are in the same class.... Institutional frameworks stopped regulating (or coercing) human relationships as they used to. In other words, institutional frameworks stopped guaranteeing human relationships, and relationships have become unstable. One can freely choose one's friends. But as others also have that liberty, one may not be chosen as a friend by others. Freedom is accompanied by the risk of being unable to be chosen as someone's friend. ... In such a situation, unless people continuously confirm the intimateness of their relationships, they feel unable to sustain those relationships. Therefore, although they are supposed to

young people's desire to connect via cell phones and the internet and also their fear of being excluded from such networks. And the simple act of recognition: 'Likes.' There is no longer a grand narrative (ōkina monogatari 大きな物語) that gives everyone a common view of life and of the contemporary age, and different people are respectively searching for various ways of life. Moreover, membership groups such as families, local communities and companies, which used to provide their members with safety and to satisfy their social needs, have been significantly weakened. Therefore, I believe that young people now have a stronger desire to constantly check their relationships with others and ascertain their own social positions by the act of recognition" (Sakurai 2015: $32)$. 
be satisfied with their human relationships (because they have chosen the relationships by their own will), they become increasingly uneasy and anxious at the same time. ... ${ }^{13}$

Doi further argues that the parents-children relationship also suffers from instability because parents have become like "friends" to their children instead of being traditionally authoritative parents. "It is true that a home may become cozier with a more open atmosphere if parent-child relationships change from vertical ones to horizontal ones. ... However, as parent-child relationships become more equal, children feel that they can no longer trust and rely on their parents wholeheartedly. Just as in the case of their relationships with friends, they are worried that their parents may not love them unless they meet their expectations and please them" (Doi 2014: 14).

In light of Doi's argument, it can be said that the tsunagari wedding, in which relationships between parents and children are made visible and highlighted, is a religious expression of the uneasiness of human relationships among young Japanese people today. Similarly, Shibuya Halloween can be seen as a performance of excessive SNS "likes" as mutual recognition in an off-line gathering. NTT Advertising, Inc. conducted an internet poll in 2016 to find out young people's reasons for attending the Shibuya Halloween party. The top five answers were: "It looked like fun" (81.2\% of the respondents), "To make good memories" (39.7\%), "To have an exciting time with friends" (35.7\%), "To see what it was like" (22.1\%), and "To deepen friendship with my friends" (19.7\%). These scores were much higher than purely self-oriented motivations such as "Because I was stressed out" (15.4\%), "To be enthusiastic" (12.7\%), "To experience something extraordinary" (7.3\%), "To follow trends" (6.3\%) (NTT Ad 2015: 16-25). ${ }^{14}$

13 Doi $(2014: 9,13)$. In order to underscore that these arguments do not solely belong to one sociologist, let me introduce a data-based collective work on Japanese young people by a group of sociologists (Fujimura et al. 2016). Chapters that are particularly relevant are 3, 6 and 7. The title of Chapter 7 alone suggests the change that Doi discusses here: "Jōnetsu' kara 'Kankeisei' o jūshi suru renai e: 1992nen, 2002nen, 2012nen chōsa no hikaku kara" 「情熱」から「関係性」を重視する恋愛へ—1992 年、2002 年、2012 年調査の比較 から (From 'Passion' Centered Love to 'Relation' Centered Love: A Comparison between Surveys Conducted in 1992, 2002, and 2012).

14 Some may say that Shibuya Halloween is limited to one location and, therefore, cannot represent a national trend. On the contrary, the quoted data has been used not only by NTT Advertising, Inc. but also by the media, assuming that it does represent current young people's behavior. It is argued that the data show young people take part in the festival to reinforce their human relationships. Cf. “Shibuyateki gunshū kōdō no nazo” 渋谷 的群衆行動の謎 (The mystery of Shibuya-style mass behavior), Withnews (a news site 
Let me give two more examples of new religion as human relationships. One is pre-birth memories or "memories in the womb."15 This example shows that children and their parents both seek mutual recognition. An obstetriciangynecologist named Ikegawa Akira published his first book on pre-birth memories in 2002. According to Ikegawa, pre-birth memories were first taken as occult, rather bizarre phenomena when he published the book. Nevertheless, the idea spread to a wide circle of mothers and pregnant women after it was featured on major information websites on child rearing in the 2010s. A documentary movie was released in 2013 and an English translation of Ikegawa's book was published in 2016. At a glance, pre-birth memories may look similar to "past life memories," a popular idea among New Agers and spiritual people. However, while "past life memories" give meaning to a person in the process of soul-searching and self-realization-as seen in the typical example of Shirley MacLaine's Out on a Limb - discourses on "pre-birth memories" are centered on the positive "recognition" of mothers by their children. In this case, children are believed to "choose" their mothers out of many women in order to love them, which can be seen clearly in the titles of Ikegawa's books: Mom, I Have Been Loving You So Much Since before I Was Born (2009) and Your Children Were Born in Order to Bring You an Important Message (2016). "Pre-birth memories" have drawn the attention of people who are eager to enhance not the well-being of children, but the self-esteem of mothers. While children, as Doi argues, are uncertain if they are loved and needed by their parents, women are also uncertain whether they can be mothers and whether giving birth to someone is the right choice. Although pre-birth memories are often wrapped in heartwarming stories, some people criticize them for being an egocentric use of infants by their mothers. ${ }^{16}$

The other example is the "goshuin 御朱印 (red seal/stamp) boom" in the mid-2010s. Temple and shrine visitors bring books called goshuinchō 御朱印 帳 to have them stamped with the temple or shrine's name. The stamps serve as proof of pilgrimage to that location. The practice itself is old, although it is unknown exactly when it started. It is a kind of custom that Ian Reader

run by the Asahi Shimbun Company), 1/14/2016 available at https://withnews.jp/article/ fo16o1140ooqqoooooooooooooooWoo80401qq0ooo12910A (accessed 29 March 2019).

15 This example was suggested by a graduate student who took my course on non-religiousness in fall 2018.

16 See, for example, "Tainai kioku no umi no oya ga aratani teishō suru 'ebidensu yori monogatari ni motozuku shindan-chiryō' ga ikani kikenka” 胎内記憶の生みの親が新たに提 唱する「エビデンスより物語に基づく診断・治療」がいかに危険か (How Dangerous the Idea of Pre-birth Memories Is: Remedies Based on Stories and Not on Evidence). Wezzy (May 24, 2018), available at https://wezz-y.com/archives/54934 (accessed 29 March 2019). 
and other scholars of Japanese religions frequently regard as "practically religious" (Reader and Tanabe 1998), that is, lacking any concrete sense of faith and mostly oriented toward this-worldly benefits (genze riyaku 現世利益). However, the recent goshuin boom offers something other than genze riyaku. Horie Norichika points out that when he asks them what goshuin is for, both goshuin practitioners and salespeople of goshuinchō respond that "what is beneficial is the relationships (goen ご縁) with deities or buddhas [formed by having goshuin], rather than a fulfillment of a particular practical wish." He quotes from a "miko 巫女 (shrine maiden) writer" who says that goshuin is "proof of offering a copy of a sutra (nōkyo 納経), and also proof of establishing relationships with a god or a buddha" (Horie 2018: 26). She further states that,

Using goshuinchō, we can feel the "relationships" (goen) with shrines and gods that we have built one by one, and we then visit many more various places ... That is a "treasure-hunting"-like time for us, Japanese people. We find something important for our lives one by one, that are hidden deep down in the culture inherited from the past. ${ }^{17}$

Horie names that aspect of the goshuin boom shinri riyaku 心理利益 or psychological benefits. The argument that spiritual movements, in which Horie includes the goshuin boom, offer psychological "healing" (iyashi 癒し) in contrast to the "salvation" (sukui 救い) offered by traditional religious worldviews is not new. What is striking in his findings is that goshuin practitioners explicitly seek relationships with deities rather than the experience of being healed or relaxed. Deities and buddhas are viewed not as objects of worship or belief, but as agents with whom to develop relationships. Although they are not "human" per se, they form a part of religion as human relationships. A chairperson of Goshuin no Kai 御朱印の会, Association for Goshuin Practitioners, to whom Horie refers, says,

What is also so attractive about goshuin is that, by looking over the book again, we can face the gods one again and remember people, sceneries and food we encountered during our trips. Goshuinchō is full of memories in addition to benefits. ${ }^{18}$

17 Horie (2018: 26-27). Quoted from an article in the June 19, 2014 issue of Josei Sebun 女性 セブン.

18 Horie (2018: 26). Quoted from an article in the April 12, 2018 issue of DRESS. 
The word "memories" here implies that relationships with gods are imagined as an extension of relationships that one builds with other human beings.

\section{$6 \quad$ Conclusions}

The differences between traditional religion and new religion as human relationships can be summarized as follows. Yanagawa's examples of religion represent the folk religion of a Gemeinschaft. Ancestor worship does not look "religious" enough in light of the Western concept of religion, and, hence, contemporary Japanese people tend to identify their practices as non-religious. However, from a Durkheimian viewpoint, God is a symbolic form of society. Supernatural ancestor spirits are the symbolic representations of human relationships within a community. In the process of urbanization, such muracentric communities came to be dissolved, and the traditional form of family came to be replaced by the modern nuclear family. The change has resulted in the decline of the traditional religion of human relationships centered on ancestor worship.

The current religion of human relationships is an attempt to re-sacralize human relationships. The difference from mura-religion is that people do not symbolize the relationships with supernatural beings. Instead, they directly venerate tsunagari, regarding it as valuable in itself. The examples I have used are practices that not only valorize tsunagari but also playfully employ rituals and festivals originating in traditional religions, such as Halloween and wedding ceremonies, as forms of expression of and engagement in tsunagari. In that respect, the current religion of human relationships is not religious, but not entirely secular, either.

In ever more fluid contemporary society, people have to work hard in order to build relationships in the intimate sphere. And they do so in order to be recognized by others and gain self-esteem. As the desire to be recognized is stronger among people with an uncertain sense of identity, new religion as human relationships can more often be observed among young people. In contrast, traditional religion as human relationships was centered upon patriarchs, who were obliged to maintain the pre-existing ie-mura system.

The contemporary religion as human relationships may be particularly pronounced in Japan, where young people are generally low in self-esteem as compared with those in other countries. According to a survey conducted by the Cabinet Office of Japan in 2013, young people in Japan scored the lowest among young people in seven countries on the question of whether they were satisfied with themselves. While between 70 and go percent of the respondents 
(ages 13-29) from the other six countries ${ }^{19}$ answered "Agree" or "I kind of agree" [that I am satisfied with myself], only 45.8 percent of Japanese respondents responded affirmatively. ${ }^{20}$ Nevertheless, fluidity is a feature of many contemporary societies in the world, and it would be no surprise if young people in other countries, like the nones in England whom Day interviewed, have come to believe in and practice belonging due to an increased uncertainty of their identities.

In their editorial for a special journal issue on the formation of the secular in Japan, Rots and Teeuwen write, "It is important that scholars of Japanese history and religion not only are informed about the ongoing debates on secularisms, secularities, and secularization, but they should also contribute to these debates more actively" (Rots and Teeuwen 2017: 11). With the abundant sociological analyses on tsunagari-obsessed young people in Japan, we should be able to add the theme of 'nones' to the international debates to which we can contribute.

For that purpose, it would be better not to regard religion as human relationships as a part of spirituality stemming from New Age and New Thought movements. Scholars of religion have been employing the term "spirituality" to refer to uninstitutionalized religiosity. However, whereas some people may consider pre-birth memories and the goshuin boom to be spiritual, tsunagari weddings and Shibuya Halloween, lacking a spiritual or supernatural dimension, look more secular. In contrast, the term "implicit religion," proposed by Edward Bailey in order to express such a religious aspect of secular lives, may cover tsunagari weddings but not the goshuin boom. Thus, it might be more appropriate to say that a "relationship turn" has been taking place since around 2010 in spiritual culture (as seen in pre-birth memories and the goshuin boom), nonreligious rituals and festivals (as seen in tsunagari weddings and Shibuya Halloween), and even in institutionalized religion (as seen in the active listening practice of engaged Buddhism). ${ }^{21}$

19 South Korea, the Us, the Uk, Germany, France, Sweden.

20 "Special Feature: Attitudes of Young People Living in the Present: Insights Gleaned from International Comparisons" in White Paper on Children and Young People 2014, Cabinet Office, Government of Japan, available at https://www8.cao.go.jp/youth/english/white paper/2014/pdf/sf.pdf (accessed 29 March 2019).

21 Michael Berman has done fieldwork on institution-based, interfaith chaplains who attempt to care for alienated individuals in "relationless" society, particularly in postdisaster Tōhoku. With critical eyes, Berman (2018) stresses an ironic outcome of their engagement by finding out they are actually reproducing rather than overcoming alienation. 
Traditional religion as human relationships became a public religion, as opposed to World Religions like Buddhism (shukke) and Christianity (Kirishitan) as a matter of personal choice. Religion and religions were already functionally differentiated from each other before the advent of the modern era. Religion-religions formed a structural equivalent of the modern Western binary code of the "secular/religious." Then religion came to be conceived of as "secular" by Japanese people as they imported and internalized the Western concept of "religion" and the "secular." I do not claim that this is the only precondition that has enabled Japanese people and society to readily appropriate the Western concept(s) of secularity, but I believe that this explanation is more acceptable among Japanese sociologists and scholars of religion.

Admitting that Yanagawa's original idea of "religion as human relationships" is too prototypical and problematically timeless, the explanation given in this article takes into account historical change and would make sense to scholars who are familiar with Japanese modernization debates, including the $i e-$ mura theory. It also helps us explain why some scholars say that modern Japan is, far from being secularized, quite religious. Both old and new religion as human relationships can be seen as religious, depending on how religion is defined. How religion overlaps or does not overlap with sezoku世俗, zoku 俗 and other related emic terms will be an interesting subject for further research. That, in turn, should provide us with new grounds from which to contribute to international scholarly debates on secularity, secularisms, and the relationship between social bonds and religion more generally.

\section{References}

Baker, Joseph O. and Buster G. Smith. 2015. American Secularism: Cultural Contours of Nonreligious Belief Systems. London and New York: New York University Press.

Berman, Michael. 2018. "Religion Overcoming Religions: Suffering, Secularism, and the Training of Interfaith Chaplains in Japan." American Ethnologist 45(2): 228240.

Day, Abby. 2011. Believing in Belonging: Belief and Social Identity in the Modern World. Oxford: Oxford University Press.

Dessì, Ugo. 2017. "Recent Developments in the Japanese Debate on Secularization." Journal of Asian Humanities at Kyushu University 2: 57-66.

Doi, Takayoshi 土井隆義. 2014. Tsunagari o aorareru kodomotachi: Netto izon to ijime mondaio kangaeruつながりを㮼られる子どもたち一ネット依存といじめ問題を考える. Tokyo: Iwanami.

Fujimura, Masayuki 藤村正之, Asano Tomohiko 浅野智彦 and Habuchi Ichiyo 羽㴊一 
代 (eds.). 2016. Gendai wakamono no kōfuku: Fuan shakai o ikiru 現代若者の幸福一 不安社会を生きる. Tokyo: Kōseishakōseikaku.

Fujiwara, Satoko. 2008. “Japan." Religious Studies: A Global View, ed. Gregory D. Alles, London and New York: Routledge, 191-217.

Fujiwara, Satoko. 2016. "Why the Concept of 'World Religion' Has Survived in Japan: On the Japanese Reception of Max Weber's Comparative Religion." Contemporary Views on Comparative Religion, eds. Peter Antes, Armin W. Geertz and Mikael Rothstein, Sheffield: Equinox, 191-203.

Furuichi, Noritoshi 古市憲寿 and Honda Yuki 本田由紀. 2010. Kibōnanmingoikkōsama: Piisu bōto to “shōnin no kyōdōtai” gensō 希望難民ご一行様—ピースボートと「承認の 共同体」公想. Tokyo: Kōbunsha.

Horie, Norichika＼cjkstart堀江宗正. 2018. “Dentō kaiki? Soretomo chihō shōmetsu?" 伝統 回帰？それとも地方消滅? Gendai Nihon no shūkyō jijo 現代日本の宗教事情, ed. Horie Norichika, Tokyo: Iwanami, 25-34.

Kleine, Christoph. 2013. "Religion and the Secular in Premodern Japan from the Viewpoint of Systems Theory." Journal of Religion in Japan 2(1): 1-34.

Koike, Yasushi 小池靖. 2007. Serapii bunka no shakaigaku: Nettowāku bijinesu, jikokeihatsu, torauma セラピー 文化の社会学—ネットワー クビジネス・自己啓発・トラウマ. Tokyo: Keisō Shobō.

Koike, Yasushi 小池靖. 2010. “Shinmitsuken to supirichuariti” 親密圈とスピリチュアリテ 1. Shūkyō kenkyū 宗教研究 84(2): 105-126.

LeFebvre, Jesse R. 2015. "Christian Wedding Ceremonies: 'Nonreligiousness' in Contemporary Japan." Japanese Journal of Religious Studies 42(2): 185-203.

Murakami, Yasusuke 村上泰亮, Kumon Shunpei 公文俊平 and Satō Seizaburō 佐藤誠 三郎. 1979. Bunmei to shite no ie shakai 文明としてのイエ社会. Tokyo: Chūōkōronsha.

NH K 2012. "Higashi nihon daishinsai de nihonjin wa dō kawattaka” 東日本大震災で日 本人はどう変わっ たか. https://www.nhk.or.jp/bunken/summary/research/report/ 2012_o6/201206o3.pdf (accessed 29 March 2019).

Nishio, Takeshi 西尾雄志 Yamaguchi, Ken'ichi 山口健一 and Kusaka Wataru 日下涉. 2015. Shōnin yokubō no shakai henkaku 承認欲望の社会変革. Kyoto: Kyoto University Press.

NTT Ad. 2015. “Shibuya ga hoshii wakamonotachi” シブヤが欲しい若者たち. Kūkidokuhon 空気読本 16:16-25.

Ōsawa, Masachi 大澤真幸. 2012. “Kindai” 近代. Gendai shakaigaku jiten 現代社会学事 典, eds. Ōsawa Masachi et al., Tokyo: Kōbundō.

Rawski, Evelyn S. 2015. Early Modern China and Northeast Asia: Cross-Border Perspectives. Cambridge: Cambridge University Press.

Rots, Aike P. and Mark Teeuwen. 2017. "Introduction: Formations of the Secular in Japan." Japan Review 30: 3-20. 
Saitō, Tamaki 斎藤環. 2013. Shōnin o meguruyamai 承認をめぐる病. Tokyo: Nihon Hyōronsha.

Sakurai, Yoshihide＼cjkstart櫻井義秀. 2015. “Keichō suru bukkyō” 傾聴する仏教. Shūkyō to shakai kōken 宗教と社会貢献 5(1): 29-53.

Takahashi, Norihito 高橋典史. 2012. "Sōron: Nihon shakai ni okeru shūkyo no tokuchō” 総論—日本社会における宗教の特徵. Shūkyō to shakai no furontiya 宗教と社 会のフロンティア, eds. Takahashi Norihito 高橋典史, Tsukada Hotaka 塚田穂高 and Okamoto Ryosuke 岡本亮輔, Tokyo: Keisō Shobō, 3-22.

Yamatake, Shinji 山竹伸二. 2011. “Mitomeraretai” no shōtai: Shōnin fuan no jidai 「認め られたい」の正体一承認不安の時代. Tokyo: Kodansha.

Yanagawa, Kei'ichi 柳川啓一. 1984/1991. “Gendai nihonjin to shūkyō” 現代日本人と宗 教, first published in Gendai sekai no shūkyōsei 現代世界の宗教性 from the Institute for Research on Christian Culture at the University of Sacred Heart, Tokyo, in 1984, reprinted in Yanagawa Kei'ichi, Gendai nihonjin no shūkyō 現代日本人の宗教, Kyoto: Hōzōkan (1991).

Yanagawa, Kei'ichi and Yoshiya Abe. 1978. "Some Observations on the Sociology of Religion in Japan." Japanese Journal of Religious Studies 5(1): $5^{-27}$.

Wohlrab-Sahr, Monika. 2016. "Secularity, Non-religiosity, Atheism: Boundaries between Religion and Its Other." Annual Review of the Sociology of Religion 7: 251-271.

Woodhead, Linda. 2016. "The Rise of 'No Religion' in Britain: The Emergence of a New Cultural Majority." Journal of the British Academy 4: 245-261.

Woodhead, Linda. 2017. "The Rise of 'No Religion': Towards an Explanation." Sociology of Religion $78(3)$ : $247-262$. 